\title{
Faktor Produksi Ujaran Kebencian melalui Media Sosial
}

\author{
Farra Lailatus Sa'idah ${ }^{1}$ \\ Program Studi Magister Psikologi \\ Fakultas Psikologi Universitas 17 Agustus 1945 Surabaya \\ farra_s2@untag-sby.ac.id \\ Dyan Evita Santi ${ }^{2}$ \\ Fakultas Psikologi Universitas 17 Agustus 1945 Surabaya \\ arma_luna@yahoo.com \\ Suryanto $^{3}$ \\ Fakultas Psikologi Universitas 17 Agustus 1945 Surabaya \\ suryanto@psikologi.unair.ac.id
}

\begin{abstract}
Hate speech has an indirect effect on how people communicate with one another, shifting contact from the physical world to cyberspace. Knowledge is the most important thing in the modern technological age for everybody to know what is going on in different parts of the world. With the availability of social media as a means of disseminating information as a means of disseminating the necessary information, the pattern of society undergoes a shift, either implicitly or invisibly, so that culture, ethics and norms become biased and cause conflict. This study aims to determine the factors that cause actors to utter speech in social media. This study uses a qualitative approach with the aim of obtaining a complete picture of something according to the human perspective under study. The data collection method used is documentation of hate speech on social media such as Instagram, Twitter, Facebook which leads to forms of insult, incitement, political, social, economic, and religious provocation; as well as interviews with several interviews from social media users totaling 2 people who have social media with hate speech on their accounts. Data analysis using coding, and verifying data. The results of this study are the factors that cause the perpetrators to utter hate speech, consisting of individual psychological conditions, namely psychology, environmental factors, factors of facilities, facilities, and technological advances, factors of lack of social control, factors of public ignorance, and factors of public interest
\end{abstract}

Keywords: Hate speech factor, social media, college student, technology, online hate speech

\begin{abstract}
Abstrak
Ujaran kebencian memiliki efek tidak langsung pada cara orang berkomunikasi satu sama lain, mengubah kontak dari dunia fisik ke dunia maya. Pengetahuan adalah hal terpenting di era teknologi modern agar semua orang tahu apa yang terjadi di berbagai belahan dunia. Dengan tersedianya media sosial sebagai sarana
\end{abstract}


penyebaran informasi yang dibutuhkan menjadikan pola masyarakat mengalami pergeseran, baik secara tersirat atau tak tampak, hingga budaya, etika dan norma menjadi bias dan menimbulkan konflik. Penelitian ini bertujuan untuk mengetahui faktor-faktor penyebab pelaku melakukan ujaran dalam media sosial Penelitian ini menggunakan pendekatan kualitatif dengan bertujuan memperoleh gambaran seutuhnya mengenai suatu hal menurut pandangan manusia yang diteliti. Metode pengumpulan data yang digunakan adalah dokumentasi dari ujaran kebencian di media sosial seperti instagram, twitter, facebook yang mengarah pada bentuk penghinaan, menghasut, provokasi politik, sosial, ekonomi dan agama; serta wawancara dengan beberapa wawancara dari pengguna media sosial berjumlah 2 orang yang memiliki media sosial dengan ujaran kebencian pada akunnya. Analisis data menggunakan dengan pengkodean, dan memverifikasi data. Hasil penelitian ini adalah faktor penyebab pelaku melakukan ujaran kebencian terdiri dari faktor keadaan psikologis individu yaitu kejiwaan, faktor lingkungan, faktor sarana, fasilitas dan kemajuan teknologi, faktor kurangnya kontrol sosial, faktor ketidaktahuan masyarakat, dan faktor kepentingan masyarakat

Kata kunci: Faktor ujaran kebencian, Media sosial, Mahasiswa, Teknologi, Ujaran kebencian online

\section{PENDAHULUAN}

Perkembangan teknologi informasi saat ini sudah sangat canggih dan mudah, sehingga menjadi gaya hidup bagi masyarakat di seluruh dunia, tidak terkecuali di Indonesia. Salah satu pemanfaatan teknologi informatika dengan munculnya berbagai macam situs jejaring sosial, di antaranya facebook, twitter, instagram, whatsapp, dan masih banyak yang lainnya (Febriyani, 2018). Media sosial adalah sebuah media online dengan pada penggunanya bisa dengan mudah berpartisipasi dalam memberi komentar, berbagi (mulai dari opini, foto dan juga video), dan menciptakan isi meliputi blog, jejaring sosial, wiki, forum, dan dunia virtual yang merupakan sebagai sarana kita dalam memudahkan berinteraksi dengan orang lain.

Hal ini juga berpengaruh pada hak dalam mengemukakan pendapat. Namun sebagian orang memanfaatkan media sosial ini untuk mengungkapkan hal yang negatif, di antaranya adalah ujaran kebencian yang bisa menimbulkan kebencian dan menyerang kehormatan individu ataupun golongan lainnya (Nithaqaini, 2018). Diperlukan upaya dalam mengkaji apa saja penyebab seseorang atau individu melakukan ujaran kebencian tersebut. Contoh kasus ujaran kebencian yang terjadi di Indonesia sendiri adalah kasus yang terjadi pada penghinaan suku Lampung karena sakit hati terhadap wanita bernama Lilis yang berasal dari Lampung yang diposting oleh Deni (2010). Dimana ia mengungkapkan kekesalannya di facebook pada 
linimasa dengan akun palsu. Yang menjadikan permasalahan adalah apa yang dituliskan Deni adalah penghinaan suku Lampung yang mengandung unsur SARA.

Penggunaan internet adalah kelebihan dalam kita berbagi informasi bagi manusia, selain karena dampak yang ditimbulkan, mulai dari segi positif hingga sebaliknya. Mengujarkan kebencian atau hate-speech bermula sekitar awal 2000an. Dari data yang ada hate speech semakin meningkat kuantitasnya setelah diperkenalkannya social media mulai sejak peluncuran facebook. Data yang dimulai dari pengguna internet yang meningkat pada tahun 2000 menjadi 1 persen dari total populasi penduduk Indonesia, atau sekitar 2 juta orang, kemudian meningkat sekitar 7 tahunan kemudian dengan angka yang drastis hingga 50,4 persen. Peningkatan drastis ini juga diiringi dari perubahan perilaku individu yang menjadikan sarana interaksi dua arah dan timbal balik tidak hanya secara tatap muka, tetapi juga via daring. Meskipun saat itu sudah ada friendster, twitter, yahoo, kemunculan facebook mengubah hampir sebagian orang Indonesia harus memilikinya mulai dari akun yang menampilkan data diri asli, atau akun anon yang tidak bernama.

Semakin banyaknya akun tak bernama atau akun anon menjadikan banyak individu merasa lebih bebas dalam memberikan pendapat atau opini yang sedang dirasakan oleh individu. Mulai dari kekecewaan, atau hanya komentar sederhana pada artis atau idola favoritnya, bahkan bentuk pengungkapan ujaran kebencian yang dilakukan sudah mengarah pada bentuk kejahatan tanpa mereka sadari. Masyarakat awam yang belum banyak memahami hate speech dengan kebebasan berpendapat menjadikan pengguna media sosial menuliskan pendapat terlalu bebas.

Fenomena hate speech di media sosial ini pernah dilakukan oleh Implicit Association Test yang dilakukan oleh Wade dan Travis (2008) yang menghitung kecepatan pemikiran asosiasi negatif dan positif pada seseorang dalam kelompok subjeknya, yaitu mahasiswa. Hasil penelitian Wade dan Travis menunjukkan bahwa mahasiswa kulit putih membutuhkan waktu yang lebih lama untuk memahami dan merespon kata-kata positif (seperti nama - salah satu orang kulit hitam sukses, jujur, baik) daripada kata-kata negatif yang diasosiasikan pada orang hitam (seperti kata jahat, gagal).

Dilihat dari sisi lain, dampak sosial media lainnya adalah dapat digunakan oleh banyak orang yang disebut dengan netizen dari gambar, postingan, ataupun status-status yang diunggah oleh para pengguna media sosial. Penggunaan media sosial ini sebagai sarana dalam mengungkapkan perasaan atau katarsis yang dilakukan pengguna namun bersifat lebih personal 
dan juga privacy, namun apabila telah diposting atau diunggah di media sosial hal tersebut akan menjadi konsumsi publik. Sehingga sosial media menjadi media untuk mengekspresikan perasaan, atau bersifat pribadi seperti curahan hati, senang, marah, kecewa, nasihat, pengetahuan, religiusitas, dan lain-lain.

Definisi dari hate speech sendiri menurut Black's Law Dictiniory menjelaskan bahwa ujaran kebencian sebagai ujaran yang mengekspresikan suatu ketidaksukaan atau kebencian pada suatu kelompok, seperti suku, ras atau budaya tertentu, khususnya pada keadaan dimana komunikasi yang dilakukan baik individu maupun kelompok yang mengujarkan ujaran tersebut cenderung memprovokasi dengan kata-kata yang mengandung kekerasan.

Fenomena ini secara tidak langsung, menggeser cara berkomunikasi antar individu, dari komunikasi di dunia nyata menjadi komunikasi di dunia maya. Komunikasi walaupun telah dilakukan dua arah sebagaimana mestinya, namun tidak jarang komunikasi yang terjadi tidak jarang bahwa hanya dapat diterima oleh satu pihak dan pihak lainnya melakukan komentar buruk atau jahat tanpa mengetahui siapa yang memberikan komentar. Begitu pula, eksistensi seseorang dapat diukur seberapa sering dan aktifnya seseorang di media sosial dengan kepemilikan akun pada media sosial yang ada (Zubair, 2010).

Selain itu, media sosial saat ini telah menjadi sarana berbisnis online, berbagi ide baik secara langsung maupun kata-kata atau inspirasi, mendapatkan informasi dari berbagai sumber, sehingga dimanfaatkan juga oleh niat tidak baik lainnya. Yang marak saat ini digunakan untuk berbagai praktik penipuan, intimidasi, fitnah, hasutan kebencian, dan sejenisnya. Hingga dapat disimpulkan, media sosial saat ini dapat digunakan untuk tujuan apa pun dan sulit dikontrol sebagaimana fungsi awal terciptanya media sosial untuk sarana kemudahan dalam berkomunikasi.

Dampak negatif dari media sosial lainnya adalah fenomena munculnya haters. Haters secara harfiah berasal dari bahasa Inggris yang berarti a person who hate ("pembenci" atau “orang yang membenci”) (dari http://artikata.com), sedangkan Mawarti (2018) menjelaskan bahwa haters adalah perilaku individu yang tidak segan untuk mengungkapkan kata-kata ataupun kalimat penyerangan pada orang yang dibencinya dengan kata-kata kotor, melecehkan, hingga menghina.

Pemanfaatan media sosial dan situs berita online lebih meningkat dari tahun ke tahun pun menimbulkan fenomena baru. Setiap individu menjadi merasa bebas mengungkapkan apapun melalui akun media sosial mereka. Atau bahkan berita-berita pada situs berita dengan 
mudah di share ke media sosial dan kemudian dapat dikomentari oleh netizen lainnya. Bahkan kini dalam situs berita online pun disiapkan ruang komentar untuk para pembaca.

Berdasarkan latar belakang masalah yang telah dijelaskan diambil bahwa permasalahan yang akan dikaji, penelitian ini bertujuan untuk mengetahui untuk mengetahui faktor-faktor penyebab pelaku melakukan ujaran kebencian di media sosial.

Ujaran kebencian atau hate speech mengandung makna kata yang memiliki karakteristik yang berkonotasi berbahaya dan dapat menjadi ancaman terhadap keberagaman (pluralistik) masyarakat Indonesia. Istilah hate speech berarti ekspresi yang menganjurkan hasutan sesuai dengan identifikasi pada target tertentu dengan kelompok sosial tertentu. Sedangkan definisi menurut Council of Europe Hate Speech tahun 2012 memaknai hate speech sebagai bentuk ekspresi yang menyebar, menghasut, mempromosikan dan membenarkan kebencian rasial, ketidaksukaan pada hal-hal yang berbau SARA, yang berdasarkan dari intoleransi, diskriminasi khususnya pada kelompok minoritas, imigran bahkan masyarakat migran.

Ada beberapa alasan yang mendasari hal di atas yaitu: Pertama, perbuatan provokasi yang mengarah pada ujaran kebencian dilakukan oleh individu atau kelompok yang tidak dapat toleran terhadap keberadaan individu atau kelompok lain. Kedua, ujaran kebencian yang dilontarkan mengandung muatan pesan bahwa kelompok tertentu adalah lebih rendah dari individu tersebut (sub-human) dan karena itu tidak hanya bermaksud menyakiti secara psikis tapi juga menyakiti secara nyata untuk menekan tetapi agar tidak berhak menerima perlakuan yang setara oleh negara.

Ujaran kebencian pada dasarnya adalah anti-free speech dimana ujaran-ujaran itu berkonotasi menuntut pembatasan terhadap pembicaraan yang mendukung pluralisme (pluralistic speech) atau bisa kita sebut juga dengan tidak menerima keberagaman saling toleransi pada banyaknya perbedaan. Ketiga, ujaran-ujaran tersebut mempunyai kaitan baik secara langsung dan tidak langsung dengan terjadinya diskriminasi, permusuhan dan kekerasan, mengarah pada perpecahan untuk saling membenci dan tidak menerima keadaan atau eksistensi kelompok atau individu yang tidak disukai itu.

Keempat, ujaran kebencian tercipta karena dari kesenjangan untuk saling menerima dan menghormati antar individu atau sekelompok orang dengan alasan berpendapat dan berekspresi sehingga bertentangan dengan demokrasi di mana bahwa free-speech merupakan dasar dari demokrasi itu sendiri. Dengan memperhatikan karakteristik di atas, ujaran kebencian dapat 
mengubah dan mempengaruhi tatanan sosial bahkan politik masyarakat, sehingga dapat menimbulkan konflik.

Pada perkembangan era teknologi saat ini, informasi merupakan hal terpenting untuk saling mengetahui apa yang terjadi di berbagai belahan dunia. Perubahan dalam masyarakat baik itu perubahan lebih baik atau sebaliknya. Dengan adanya media sosial sebagai wadah penyalur untuk menyebarkan informasi yang dibutuhkan menjadikan pola masyarakat mengalami pergeseran, baik secara tersirat atau tak tampak, hingga budaya, etika dan norma menjadi bias dan menimbulkan konflik. Pengertian konflik sendiri adalah suatu pertentangan dan ketidaksesuaian kepentingan, tujuan, dan kebutuhan dalam situasi formal, sosial, maupun psikologis, sehingga menjadi antagonis, ambivalen dan emosional. Hal ini lumrah baik dialami oleh individu dalam situasi yang mendukung adanya konflik itu atau tidak. Begitu pun juga dengan kelompok minoritas yang biasanya menjadi sasaran untuk menjadi alasan mengapa konflik itu terjadi.

Dampak konflik ini tak lepas dari semakin meningkatnya angka hate speech atau ujaran kebencian di tengah masyarakat, baik itu karena provokasi dari kepentingan individu atau kelompok yang memang bertujuan untuk merusak kekondusifan negara baik secara sosial, politik dan ekonomi. Kebebasan politik yang belum lama dinikmati oleh masyarakat Indonesia pasca era Orde Baru menyebabkan segala upaya untuk menekan kebebasan mudah untuk dicurigai. Peraturan perundang-undangan terkait hate speech bertautan dengan klausul tentang penodaan yang selama ini digunakan menjadi sumber legitimasi bagi diskriminasi, permusuhan dan kekerasan (persekusi) terhadap kelompok keagamaan minoritas. Serta perlu melebarkan kacamata kita dalam melihat apa saja yang dapat kita teliti dan kita pelajari dalam perubahan sosial pada masyarakat saai ini.

\section{Faktor-faktor Produksi Ujaran Kebencian}

Hate speech merupakan tindakan komunikasi yang dilakukan oleh individu kelompok dalam bentuk provokasi, hasutan, dan hinaan yang ditujukan kepada individu maupun kelompok lain yang mencakup SARA, gender, keagamaan, orientasi seksual, dan lain-lain. Terdapat beberapa faktor yang mempengaruhi terjadinya perilaku atau tindakan hate speech itu sendiri, di antaranya :

a. Faktor dari dalam diri individu sendiri, di mana individu sendiri memiliki faktor kejiwaan yang mendorong individu tersebut melakukan sesuatu, yaitu motivasi. Dalam teori 
yang diungkapkan Maslow dimana kepribadian seseorang menekankan pada hierarki kebutuhan dan motivasi. Di mana faktor dalam diri ini dapat dimasukkan pada grand theory, yaitu pada kebutuhan rasa memiliki dan juga eksistensi yang ingin diperhatikan. Perilaku hate speech sendiri menjadikan individu ingin melakukan itu, yang dimulai dari rasa iri. Seperti pada ketidakpuasan pada diri yang menganggap orang lain lebih bahagia, memiliki segalanya, ataupun lebih baik dari hidupnya.

b. Faktor dari ketidaktahuan masyarakat tentang hate speech, hal ini termasuk pada perilaku-perilaku penghinaan yang diterima oleh individu atau kelmpok, dengan alasan norma dan kewajaran di media sosial. Kurangnya sosialisasi atau informasi untuk masyarakat agar lebih perhatian atau aware pada kejahatan atau ujaran kebencian (hate speech) terhadap sesama. Dapat dilihat pada penggambaran sehari-hari pada beberapa laman media sosial yang masih menormalkan bahwa yang mendapatkan perhatian lebih baik adalah yang memiliki foto 'cantik' atau 'jelek' dengan body shamming yang sering dilakukan pada comment-comment di media sosial yang viral.

c. Faktor sarana dan fasilitas, di mana ini secara tidak langsung merupakan dampak dari media sosial yang sekarang ini menjadi kebutuhan bagi setiap individu untuk mendapatkan informasi. Pada era globalisasi saat ini media sosial cukup berpengaruh pada percepatan pertukaran informasi dan penyebarannya pun semakin mudah. Apabila sarana dan fasilitas yang mendukung ini dibarengi tanpa adanya pengawasan dan kebijakan pengguna dalam memanfaat media sosial akan menjadikan free-speech yang dimana merupakan dari anti-hate speech. Contohnya, di instagram pada tahun 2021 ada beberapa artis luar negeri yang nekat melakukan bunuh diri dikarenakan komentar jahat yang diterimanya dari media sosial. Selain itu, berita dari dalam negeri sendiri tidak jarang juga beberapa artis atau influencer yang memutuskan untuk berhenti dari dunia entertainment karena tidak kuat pada hate speech yang diterimanya dari media sosial.

d. Faktor kurangnya kontrol sosial, baik dari internal yaitu keluarga dan eksternal di antaranya masyarakat sekitar contoh paling terdekat adalah tetangga, teman atau sahabat, dan juga lingkungan bekerja atau akademik. Banyak masyarakat yang belum peduli akan kejadiankejadian kejahatan pada dunia maya, atau yang biasa kita sebut cyber crime. Hilangnya kontrol tersebut menjadikan kaburnya norma-norma sosial yang ada sehingga menimbulkan konflik. Kontrol sosial yang masih sering kita lupakan adalah sikap ketidakpedulian terhadap sesama yang menganggap bahwa mulai dari lisan, baik yang kita ucapkan maupun yang tertulis atau 
terketik dengan tangan kita menjadi tidak terkontrol dan semaunya sendiri dengan dalih permasalahan, dan adapun faktor dari kurangnya komunikasi serta sikap apatis.

e. Faktor kepentingan masyarakat, mungkin hal ini tidak bisa dikaitkan dengan perindividu. Akan tetapi, hal tersebut menjadi perlu diperhatikan karena di era globalisasi yang semakin memudahkan onformasi palsu atau hoax bermunculan juga semakin meningkatkan angka hate speech atau ujaran kebencian. Pada hal ini dapat kita lihat ketika pemilihan presiden yang menyebabkan masyarakat pecah menjadi dua kubu, di mana masing-masing kubu saling menjatuhkan satu dengan yang lain.

Adapun bentuk-bentuk ujaran kebencian atau hate speech yang dapat ditemukan:

1. Eufemisme (penghalusan atau pelembutan makna), eufemisme merupakan majas yang tujuan utamanya adalah untuk menghormati lawan bicara agar tidak merasa direndahkan dengan penggunaan istilah yang ada. Seperti yang disebutkan dalam penelitian sebelumnya oleh Eriyanto (2011) digunakan untuk memperhalus "keburukan". Contohnya, pada kalimat "enak, ya makan yang enak-enak terus, sampai lupa sama keluarganya". Kalimat yang ditujukan tersebut ingin menyinggung, namun dengan meninggikan dahulu pada lawan bicaranya.

2. Disfemisme adalah ekspresi dengan konotasi yang menyinggung baik tentang masalah individu atau kelompok, ataupun keduanya. Hal ini biasanya dimotivasi oleh perasaan seperti ketakutan, ketidaksukaan, kebencian dan penghinaan. Biasanya adanya komentar yang mengungkit atau mengandung kata-kata SARA. Seperti, "Dasar C*na!“

3. Labeling adalah pemakaian kata-kata yang ofensif kepada individu, kelompok, atau kegiatan yang bersifat menyimpang dari norma yang ada di masyarakat, yang kemudian individu atau kelompok cenderung melakukan penyimpagan tersebut. Misalnya, pada masyarakat saat ini, khususnya anak muda merasa bahwa memiliki masalah pada mental heatlh atau kesehatan mental merupakan hal yang keren, sehingga menggunakan kata-kata yang cenderung negatif untuk menggambarkan dirinya.

4. Stereotipe adalah penilaian terhadap individu atau kelompok di mana individu atau kelompok yang dimaksud dapat dikategorikan yang dimarjinalkan. Namun, stereotipe pada hate speech di sini adalah sebuah kata yang menunjukkan sifat-sifat negatif atau positif (umumnya negatif) dengan orang, kelas, atau perangkat tindakan yang mengandung pada unsur penghinaan. Seperti "anak punk itu tidak ada yang punya aturan, tidak punya pendidikan! Jangan dekati saudara saya!“ 


\section{Dampak Media Sosial}

Seperti yang sudah dijelaskan sebelumnya media sosial adalah sebuah media daring atau online. Di mana para penggunanya dapat dengan mudah berinteraksi dengan pengguna lainnya, berbagai, dan menciptakan sebuah opini atau blog, forum, dan juga dunia virtual lainnya. sederhananya, istilah media dapat dijelaskan sebagai alat. Adapun pendapat lainnya menyebutkan bahwa media sosial sebagai sebuah kelompok aplikasi yang menggunakan internet dimana individu dapat membuat sebuah web page pribadi dan terhubung dengan setiap pengguna yang tergabung dalam aplikasi media sosial untuk saling berbagi informasi dan berkomunikasi (Anang, 2016).

Diperlukan pendekatan teori-teori sosial yang memperjelas apa yang membedakan antara media sosial dan media lainnya di internet sebelum pada kesimpulan apa yang dimaksud dengan media sosial. Media Sosial adalah medium di internet yang memungkinkan pengguna merepresentasikan dirinya baik dalam berinteraksi, bekerjasama, berbagi, berkomunikasi dengan pengguna lain, dan membentuk ikatan sosial secara virtual. Pendapat lainnya dari media ini adalah new media yang merupakan sarana komunikasi yang menawarkan digitisation, convergence, interactiviy, dan development of network terkait pembuatan pesan dan penyampaian pesannya. Kemampuanya menawarkan interaktifitas ini memungkinkan pengguna dari new media memiliki pilihan informasi apa yang dikonsumsi, sekaligus mengendalikan keluaran informasi yang dihasilkan serta melakukan pilihan-pilihan yang diinginkannya. Kemampuan menawarkan suatu interactivity inilah yang merupakan konsep sentral dari pemahaman tentang new media. (Flew, 2002).

Sebutan media baru/new media ini merupakan pengistilahan untuk menggambarkan kerakteristik media yang berbeda dari yang telah ada selama ini. Media seperti televisi, radio, majalah, koran digolongkan menjadi media lama / old media, dan media internet yang mengandung muatan interaktif digolongkan sebagai media baru / new media. Sehingga pengistilahan ini bukan berarti kemudian media lama menjadi hilang digantikan media baru, namun ini merupakan pengistilahan untuk menggambarkan karakteristik yang muncul saja.

Media sosial online, disebut jejaring sosial online bukan media massa online karena media sosial memiliki kekuatan sosial yang sangat mempengaruhi opini publik yang berkembang di masyarakat. Penggalangan dukungan atau gerakan massa bisa terbentuk karena 
kekuatan media online karena apa yang ada di dalam media sosial, terbukti mampu membentuk opini, sikap dan perilaku publik atau masyarakat.

Menurut Horrigan (2000), terdapat dua hal mendasar yang harus diamati untuk mengetahui intensitas penggunaan intenet seseorang, yakni frekuensi internet yang sering digunakan dan lama menggunakan tiap kali mengakses internet yang dilakukan oleh pengguna internet. The Graphic, Visualization \& Usability Center, The Georgia Institute of Technology (dalam Michell, 2002) menggolongkan pengguna internet menjadi tiga kategori dengan berdasarkan intensitas internet yang digunakan: 1) Heavy users (lebih dari 40 jam per bulan), 2) Medium users (antara 10 sampai 40 jam per bulan), dan 3) Light users (kurang dari 10 jam per bulan).

\section{METODE}

Metode penelitian yang digunakan dalam penelitian ini adalah pendekatan kualitatif dengan tipe penelitian grounded theory. Unit analisis dalam penelitian ini adalah ujaran kebencian melalui media sosial pada mahasiswa. Penelitian ini melibatkan mahasiswa yang terlibat langsung pada fenomena ujaran kebencian di media sosial. Selain menggali data dari kedua subjek utama, penelitian ini juga menggali data dari significant others subjek. Informan dalam penelitian ini adalah 2 pengguna aktif media sosial yang masih berusia 16-30 tahun, yang terdapat komentar jahat (ujaran kebencian) atau berkomentar yang mengandung SARA. Baik berjenis kelamin laki-laki dan perempuan. Teknik penggalian data yang digunakan dalam penelitian ini adalah teknik wawancara dan observasi dengan mengamati laman media sosial. Metode wawancara yang digunakan dalam penelitian ini adalah wawancara mendalam atau depth interview, yakni untuk memperoleh pemahaman secara menyeluruh dan mendalam mengenai ujaran kebencian. Proses pengorganisasian dan analisis data Proses pengorganisasian dan analisis data dimulai dengan mengorganisasikan data terlebih dahulu. Dengan data yang beragam, penulis mengorganisasikan data dengan rapi, sistematis dan selengkap mungkin (Poerwandari, 2011).

\section{HASIL DAN PEMBAHASAN}

Penelitian ini melakukan orientasi lapangan tentang kemungkinan dilakukannya penelitian sesuai dengan tema yang peneliti lakukan sebelum melakukan penelitian. Orientasi dilakukan pada bulan Agustus 2019 dengan melakukan wawancara awal pada hasil observasi 
laman social media dari masing-masing macam social media, untuk memperoleh gambaran umum dari faktor-faktor atau alasan ujaran kebencian terseut dilakukan pada media sosial.

\section{Subjek 1}

DM adalah seorang guru BK dan juga mahasiswa yang sedang menempuh magister, berusia 28 tahun, pada penelitian ini DM merupakan mediator yang menangani. Sering menangani kasus bullying pada siswanya yang berawal pada media sosial. Mulai dari beritaberita hoax yang menyebar di media sosial, dan komentar-komentar yang menjadi penyebab bully atau perisakan yang dialami murid-murid dan dirinya sendiri. Perbedaan pendapat alasan terbanyak menjadi pemicu terjadi ujaran kebencian satu dengan yang lain. DM sendiri menuturkan dalam wawancaranya menangani anak-anak yang bermasalah dengan bullying dimulai dari perbedaan pendapat. Berlanjut pada perundungan (bullying) baik di real life maupun di media sosial yang berupa hate speech. Banyak dampak yang dirasakan korban mulai dari pengucilan. Korban merupakan murid yang ditangani DM ketika bekerja. Korban (FT) pertama kali melaporkan kejadian bullying yang diterimanya dari teman-teman sekolahnya. Dinamika psikologis yang didapatkan dari penuturan DM sebagai konselor adalah adanya perasaan rendah diri yang cukup signifikan dari perubahan yang sebelumnya FT adalah peibadi yang cukup terbuka, menjadi pribadi yang lebih tertutup dan adanya keterbatasan pada pengungkapan emosi yang sedang dirasakan pada orang-orang di sekitarnya. FT lebih memilih untuk memendam saja, dan menutup diri di dalam kamar. Hal tersebut dibenarkan oleh pernyataan keluarga di mana ketika DM melakukan kunjungan atau home visit ke rumah FT.

Komentar-komentar jahat yang datang bergantian dari berita yang sedang trending saat itu, dan perbedaan pendapat dalam menanggapi permasalahan dari berita tersebut. DM merasa hal tersebut sebenarnya dapat diminimalisir dengan sosialisasi dan pengawasan ligkungan. Namun, hal ini juga perlu dilakukan dengan pengadaan sosialisasi dan penanaman moral untuk saling menghargai antar manusia agar dapat menerima dan saling menghormati satu dengan yang lain, mengingat Indonesia adalah negara yang berisi banyak suku dan budaya, pemahaman akan moral untuk saling menghargai dan toleransi harusnya ditanamkan sejak dini.

Dari segi lingkungan keluarga dan juga lingkup pertemanan menjadi lingkaran untuk menjadi salah satu faktor dari hate speech itu sendiri. Mulai dari pola asuh dengan menggunakan kata-kata yang tidak pantas atau pengarahan dan pengajaran dari orang tua ke anak yang tidak sepantasnya, menjadi contoh anak-anak dalam berinteraksi baik di dunia nyata atau real life dan juga di media sosial. 


\section{Subjek 2}

AS adalah salah satu korban hate speech/bullying di media sosial, di mana AS mendapatkan ujaran kebencian yang diberikan oleh teman seangkatan di facebook. Ujaran kebencian yang didapatkan lantara AS memposting salah satu calon presiden dalam laman profile-nya, dan kemudian mendapat komnetar yang bernada tidak menyenangkan dari salah satu user yang bahkan tidak berteman dengan AS. Permasalahan ini memang tidak dibawa AS ke ranah hukum, atau penanganan lebih lanjut, karena AS merasa bahwa komentar-komentar yang diterima memang wajar dan pasti akan ada pihak yang tidak setuju dnegan pendapatnya.

Ujaran kebencian atau komentar jahat tersebut mulai mengganggu ketika mulai mendapatkan komentar serta pesan pada media sosialnya, yaitu facebook yang mulai bernada ancaman. Dengan embel-embel antek yang selalu didapatkan AS hanya merasa khawatir pada lingkup pertemanan dan keluarganya. Dan hal tersebut benar terjadi, AS mendapat beberapa komentar jahat (hate speech) dari kertas-kertas bekas yang ditinggalkan di motornya. Entah ulah iseng atau memang bertindak kriminal dengan nada mengancam. Sejauh ini AS tidak mendapatkan perlakuan terlalu signifikan, namun tetap merasakan kecemasan-kecemasan yang bisa saja terjadi kapan saja.

Proses ujaran kebencian terjadi dikarenakan bermula dari kekecewaan yang terjadi pada realitas yang ada di lingkungan. Mulai dari permasalahan politik, personal, yang berhubungan dengan SARA, dan lain-lain, menjadi pemicu komentar-komentar yang akhirnya menjadi ujaran kebencian.

Dalam wawancara yang telah dilakukan, menurut subjek I ujaran kebencian diarahkan kepadanya karena rasa benci dan iri dari apa yang ditampilkan subjek di media sosial. Mulai dari foto, caption foto, bahkan hanya tulisan kadang menjadi pemicu ujaran kebencian bagi haters.

Tidak menutup kemungkinan juga kadang ujaran kebencian itu langsung di pesan yang hanya bisa dibaca oleh subjek. Menggunakan kalimat-kalimat yang tidak panas, disertai dengan gambar-gambar yang tidak senonoh. Hal ini menjadi pemicu karena memang tidak semua orang menyukai orang lain sepenuhnya, pasti ada beberapa orang yang tidak suka.

Hal ini berdampak pada lingkungan sosial yang dirasakan oleh subjek. Subjek merasa kadang tertekan karena uajran kebencian yang diterima berasal dari akun tak bernama atau akun anon, dimana bisa menjadi siapa saja pelaku yang melakukan ujaran kebencian tersebut. 
Sedangkan subjek II adalah salah satu penerima atau pernah terlibat masalah dari komen yang pernah dilakukan di Twitter, yang menjadikan orang lain melakukan komen balik dengan ujaran kebencian karena komentar mendukung salah satu calon presiden. Dampak dari kejadian tersebut tidak terlalu signifikan atau berpengaruh dalam kehidupan sosial subjek.

Hal tersebut dikarenakan pemikiran subjek terhadap permasalahan tersebut tidak terllau dianggap pusing sebagai sesuatu yang mengancam atau membahayakan hidupnya. Meskipun, bisa dibilang ujaran kebencian yang diterimanya cukup sering karena terang-terangan mendukung, namun tidak pernah membuat suatu caption atau pernyataan yang mengarah pada kebencian. Tidak jarang ujaran kebencian menyasar lebih dari satu identitas yang melekat dalam diri objeknya.

\section{SIMPULAN}

Hate speech merupakan tindakan komunikasi yang dilakukan oleh individu kelompok dalam bentuk provokasi, hasutan, dan hinaan yang ditujukan kepada individu maupun kelompok lain yang mencakup SARA, gender, keagamaan, orientasi seksual, dan lain-lain. Ujaran kebencian yang seringkali ditujukan kepada mahasiswa tidak hanya dikarenakan lingkungan yang kurang mendukung adanya media atau tempat atau wadah yang tidak terkontrol, dapat dipicu oleh adanya iri hati (ketidakpuasan); dimana tidak semua orang bisa menerima apa yang diekspresikan oleh orang lain, misalnya bisa terjadi pada seniman atau hal tersebut biasanya bertentangan dengan norma dan kebiasaan masyarakat yang ada di sekitarnya; kesenjangan kapitalis, dimana semua orang sudah memiliki pandangan, dan tidak sedikit yang memaksakan pandangannya atau pendapatnya diterima oleh orang lain; dendam, dimana kadang sebagai bentuk coping dari pengujar kebencian mengungkapkan apa yang dirasakannya tanpa melihat norma dan menutupi tanpa mengungkapkan identitas mereka, dan rasa sakit hati tersalurkan; dampak yang ditimbulkan dari ujaran kebencian ini berbeda untuk setiap individu, tetapi tidak menutup dampak negatif dari ujaran kebencian untuk kelangsungan hidup individu juga dapat mempengaruhi, karena salah satu bentuk dari bulliying.

\section{DAFTAR PUSTAKA}

Albertine, M. (2010). Psychology of Literature: Literary Works, Methods, Theories, and Case Examples (2nd ed.). Jakarta: Torch Library Foundation.

Alivermana, W. (2014). Contemporary Issues of Islamic Education. Yogyakarta: Deepublish. 
Anwar, Firdaus. (November, 2015). Fenomena Penyebar Hate Speech Dilihat dari Kacamata Psikologi. detik.com. https:/health.detik.com/berita-detikhealth/d3060430/phenomenon-spreader-hate-speech-see-from-glasses-psychology.

Bryan A. Garner (Ed). (2004). Black's Law Dictionary, (8th ed.). West Group, St. Paul Minnesota

E. Jubilee., \& A. Nugroho. (2012). Kuasai Fotografi Digital dan DSLR dari Nol. Jakarta: PT. Media Elex Komputindo.

Erdianto, K. (2017). Hate Speech Triggers Young Generation Intolerant and Discriminatory.

F. Hartono, SJ. (2007). Injured Child-Magic Child. 5th printing. Yogyakarta: Kanisius.

Flew, T. (2001). New Media: An Introduction. New York: Oxford University Press,

Frandsen, F., \& Winni, J. (2011). The Study of Internal Crisis Communication: Towards An Integrative Framework. Corporate Communication: An International Journal, 16(4).

Henslin, J. M. (2006). Sociology with Grounded Approach. Volume-I, 6th Edition. Translator Kamanto Sunarto. Jakarta: Erlangga Publisher.

Herawati, \& Pulungan, I. (2006). Factors Related to Contact Farmer Participaption in Agricultural Extension Progam Planning. Jurnal Penyuluhan, 2(2).

Horrigan, J. B. (2000). New Internet Users: What They Do Online, What They Don't, and Implications for the 'Net's Future, pewinternet.com. http://www.pewinternet.org/pdfs/New_User_Report.pdf

Husin, B.R., Febriyani, M., \& Sunarto. (2018). Analisis Faktor Penyebab Pelaku Melakukan Ujaran Kebencian (Hate Speech) dalam Media Sosial. Jurnal Poenale, 6(3).

Kartono, K. (2001). Social Pathology. Jakarta: Rajawali Press.

Mawarti, Sri. (2018). Hate Speech Phenomenon: Impact Of Hate Speech. Tolerance: Communication Media for Religious People. Vol. 10, No. 1, January. Pekanbaru, Riau: UIN SUSKA Publisher.

Muzammil Sanusi. (2010). The Hacking the Data Breaker. Jakarta: PT. Elex Komputindo.

Poerwandari, Kristi. (2001). Qualitative Approach to Research in Human Behavior. Faculty of Psychology, University of Indonesia: Institute for Development of Psychology Measurement and Education Facilities (LPSP3).

Priyatna, A. (2010). Let's End Bullying: Memahami, Mencegah \& Mengatasi Bullying. Jakarta: PT. Elex Media Komputindo.

Sitompul, J. (2013). Handling of Cyber Crime in Indonesia. Jakarta: Erlangga Publisher. 
Sullivan, K., Cleary, M., \& Sullivan, G. (2005). Bullying In Secondary Schools.

Wade, Carole., Carol Travirs. (2008). Psychology. (9th Ed.). Jakarta: Erlangga Publisher.

Weber, A. (2009). Manual on Hate Speech. France: Council of Europe Publishing. California: Corwin Press.

Zubair, Agustina. (2010). The Phenomenon of Facebook: The involvement of Communication Technology in The Development of Human Communication. Journal ASPIKOM, 1(1). 